\title{
Die vraag na Bybelse gronde vir die onderskeiding in Bearbeidingswyse tussen die heidensending en die arbeid onder buitekerklikes - enkele Nuwe Testamentiese riglyne
}

\author{
A G van Aarde
}

\section{Inleiding}

Die ondersoek in die Nuwe Testament na 'n onderskeiding in bearbeidingswyse tussen die heidensending en die arbeid onder buitekerklikes kom uit die staanspoor voor probleme te staan. In die eerste plek veral vanweë die feit dat die Nuwe Testament in 'n missionêre situasie tot stand gekom het en dat die arbeid onder buitekerklikes nie ' $n$ wesenlike aangeleentheid vir die kerk in die Nuwe Testamentiese tyd was nie. Die Raad vir die arbeid onder buitekerklikes onderskei volgens sy handleiding verskeie kategorieë van mense wat as buitekerklikes gereken moet word. ${ }^{1}$ Dit word verder in twee oorkoepelende hoofgroepe ingedeel, naamlik (1) mense wat formeel nog lidmate van die kerk is, maar deur hulle leer en wandel te kenne gee dat hulle op pad uit die kerk is, en (2) mense wat al sover gegaan het dat hulle geheel-en-al buite die kerk te staan gekom het, en met wie die kerk nie meer direkte kontak het nie. Die 58ste Algemene Kerkvergadering van die Nederduitsch Hervormde Kerk van Afrika ${ }^{2}$ besluit egter in hierdie verband dat die vrae in verband met die lidmate wat besig is om buitekerklik te word, eerder onder die opsig en tug tuishoort en nie by die vrae oor die arbeid onder buitekerklikes nie. Die Nuwe Testament spreek hom nie formeel hieroor uit nie. Dit bly dus wesenlik 'n probleem om uit te maak wie in die Nuwe Testament as buitekerklikes gekwalifiseer moet word.

Hierdie studie het egter nie tot doel om uit te maak wie as buitekerklikes gereken moet word nie. As 'n breë riglyn maak ons gebruik van die reeds vermelde oorkoepelende indeling soos deur die genoemde handleiding uiteengesit. Wat die arbeid aan heidene betref, het ons uit die aard van die saak natuurlik nie dié probleem nie, behalwe die vraag na die arbeid onder Israel. Vir die doel van hierdie studie word verder nie hierop ingegaan nie, en word sodanige Nuwe Testamentiese gedeeltes verbygegaan.

'n Verdere aangeleentheid wat vir die aanpak van sò 'n ondersoek in ag geneem moet word, is die bydrae van die resente ontwikkeling van die Algemene Taalwetenskap, en in die besonder op die gebied 
van die Nuwe Testamentiese Grieks, vir die eksegese van die Nuwe Testament. Baie oorsigtelik kan slegs die volgende in hierdie verband opgemerk word. Daar moet daarteen gewaak word dat nie meer in ' $n$ woord of 'n teksvers ingelees word as wat linguisties en teologies aanvaarbaar is nie. Daar moet gedurig ook in gedagte gehou word dat betekenis oor woordgrense, singrense en selfs perikoopgrense strek. Woorde, sinne en perikope word deur die spreker of outeur in bepaalde relasies tot mekaar gebruik om so betekenis en derhalwe kommunikasie moontlik te maak. Om 'n ondersoek te loods na die betekenis van 'n bepaalde woord in 'n bepaalde konteks, verg dus 'n ondersoek op 'n semantiese, sintaktiese en konteksuele vlak. Om dus vas te stel wat die skopus van 'n bepaalde perikoop is, moet die struktuur van die gedeelte by wyse van gesonde taalkundige reëls vasgestel word. ${ }^{3}$ Vir hierdie studie is dit in hierdie opsig ter sake dat ons naamlik nie vanuit 'n bepaalde woord of teksvers ' $n$ bearbeidingswyse sal kan aflei nie. Eers nadat ons die struktuur van die perikoop vasgestel het, sal ons kan vasstel of daar 'n bepaalde bearbeidingswyse uit die opbou van die argument af te lei is. Uit die aard van die saak is die objektiewe afbakening van 'n perikoop 'n absolute vereiste. Dit word gedoen met behulp van kriteria soos herhalinge, spanninge en verskille in sinsbou en lekseemvoorkeure in bepaalde tekste. ${ }^{4}$ Hierdie perikoopafgrensing word deur die teksanalise self gekontroleer. $\mathrm{Na}$ my oortuiging is dit die enigste legitieme wyse van ondersoek, en om hieraan te voldoen, sou dit dan nodig wees om die Nuwe Testament in sy wydste sin in oënskou te neem. Dit is egter nie in so 'n ondersoek soos hierdie moontlik nie, en daarom word daar slegs 'n seleksie gemaak van 'n paar gedeeltes wat oënskynlik betrekking het op die saak onder bespreking. Die seleksies word gegroepeer in onderafdelings, naamlik die aardse Jesus, die dissipels/apostels in die vroeë tyd, Paulus en die Hebreërbrief.

\subsection{Die aardse Jesus}

Twee seleksies is hier gekies, naamlik Lukas 9:51-10:24 en Lukas 15:1-32. Eersgenoemde wil op die oog af lyk of dit op 'n heiden(?)sending betrekking kan hê, en laasgenoemde op afgedwaal des binne die eie kring.

(a) Lukas 9:51-10:24: Hierdie Skrifgedeelte grens hom baie duidelik teen die voorafgaande en die daaropvolgende af. Drie perikope kan binne die gedeelte afgebaken word, wat in opvolgende relasie tot mekaar staan, naamlik 9:51-56; 9:57-62 en 10:1-24. Oorsigtelik vertoon die opbou van die redevoering in hierdie hele Skrifgedeelte die volgende struktuur:

A. 'n Samaritaanse dorp weier om Jesus te ontvang (verse 51-56). 
B. (1)' $n$ Persoon wil uit eie inisiatief Jesus onvoorwaardelik as dissipel volg. Hy word deur Jesus gekonfronteer met 'n realiteit van dissipelskap (verse 57-58).

(2) Jesus nooi 'n persoon uit om Hom te volg. Die man is daartoe bereid, maar vra vanweë sy daaglikse verantwoordelikhede uitstel. Met ' $n$ spreekwoord wys Jesus die man se argument af as nie ter sake nie, en korrigeer sy gesindheid met die opdrag om die Koninkryk van God te gaan verkondig (verse 59 en 60 ).

(3) 'n Persoon wil Jesus volg, maar stel voorwaardes. Jesus konfronteer hom met die realiteit dat hy nie met so 'n gesindheid kan kwalifiseer nie (verse $61-62$ ). ${ }^{5}$

C. (1) Die Kurios stel 70/72 mense aan (vers 1a).

(2) Twee-twee word na elke dorp en plek gestuur waarheen $\mathrm{Hy}$ van plan is om te gaan (vers 1 b).

(3) Fundering van die sending: Die oes groot en die werkers min (vers 2).

(4) Aard van arbeidsveld word geskets met behulp van metafoor: soos lammers tussen wolwe (vers 3 ).

(5) Opdrag oor wyse van uitvoering:

(a) haastigheid (vers 4);

(b) vredesaankondiging vir dié huise wat gereed is om dit te ontvang (vers 5-6);

(c) nie na ' $n$ ander huis gaan as dié een gewillig is om in hulle lewensbehoeftes te voorsien nie. Die uitvoering van die opdrag is ook van groter belang as die kwelling oor rituele rein of onrein voedsel (vers 7).

(d) as 'n dorp die boodskappers ontvang, moet hy die aangebode gasvryheid aanvaar, siekes gesondmaak en aan hulle verkondig dat die Koninkryk van God ' $n$ teenwoordige realiteit is (vers 8-9);

(e) as 'n dorp hulle nie ontvang nie, moet hulle die dorp duidelik laat verstaan dat hulle nie die minste in gemeen met die plek het nie, maar dat hulle tog moet weet dat die Koninkryk van God 'n teenwoordige realiteit is (verse 10-11).

(6) Oordeelsuitspraak oor die betrokke ongehoorsame stad (vers 12).

(7) Wee-uitroep oor soortgelyke ongehoorsame stede: Gorasin, Betsaida, Kapernaüm (verse 13-15).

(8) Opdrag van die Kurios word afgesluit: Christus vereenselwig Hom met sy gesante. Hulle werk is ook sy werk en daarom kan hulle met gesag optree (vers 16).

(9) 70/72 keer met blydskap terug (vers 17).

(10) Christus se antwoord aan hulle na suksesvolle sending (verse 18-20).

(11) Christus jubel en loof/dank God (vers 21).

(12) Christus spreek 70/72 en ander teenwoordiges toe (vers 22).

(13) Christus wend Hom tot die Twaalf. 'n Afsluiting van die 
episode van die 70/72 en die oorgaan tot 'n volgende redevoering (verse 23-24).

\section{Opmerkinge:}

(1) Al drie hierdie perikope het opvallend sy eie skopus, naamlik: $A=$ 'n Samaritaanse dorp weier om Jesus te ontvang.

$B=$ ' $n$ Onderwys oor die betekenis van dissipelskap na aanleiding van die gebeure in $\mathrm{A}$.

$C=$ Die uitstuur van die 70/72 om die Koninkryk van God te verkondig.

(2) Al drie die perikope dra egter by om die een oorkoepelende skopus te dien, naamlik dat die Koninkryk van God in Jesus Christus aangebreek het en dat om dissipel te wees, beteken dat hierdie heilsfeit verkondig moet word.

(3) In 9:57-62 (seksie B) kon ons in afgeleide sin praat van mense wat deur hulle gesindheid te kenne gee dat hulle geen begrip het vir die betekenis en die eise van die Koninkryk van God nie. Die metode wat Jesus in sy "bearbeiding" aan hulle volg, is om hulle op hulle dwalinge te wys en die regte weg aan hulle voor te hou, naamlik om met die afstanddoen van alle eie belang die Koninkryk van God te verkondig. Indien hulle nie daartoe bereid is nie, is hulle nie vir hierdie opdrag geskik en aanvaarbaar nie.

(4) In 10:1-24 (seksie C) kan daar nie met sekerheid afgelei word of 'n mens hier met sending aan die heidene te doen het nie. Baie geleerdes wil in die getal sewentig 'n simboliek sien wat die bedoeling sou hê om voorsiening te maak vir die toekomstige proklamasie van die evangelie aan al die nasies van die wêreld ${ }^{6}$ Op grond van gesaghebbende teksgetuienis moet egter voorkeur gegee word aan die getal twee-en-sewentig. ${ }^{7}$ Die parallel in Matteus 10:5(b) steun ook nie die opvatting dat hier sprake is van heidensending nie.

"Moenie met ' $n$ pad na die heidennasies afdraai nie en moenie in 'n dorp van die Samaritane ingaan nie. Gaan liewer na die verlore skape van die volk Israel." Uit die kontekstuele verband in Lukas wil dit egter lyk of die sending in Samaritaanse gebied plaasvind en sonder onderskeid alle inwoners geld van die dorpe waarheen die boodskappers gestuur word. Hierdie feit moet dus benewens die Samaritane ook heidene insluit. Die metode van "bearbeiding" kan dan uit verse 4-11 afgelei word, naamlik ' $n$ vermyding van alles wat die aandag van die opdrag sal aflei, die aanvaarding van die aangebode gasvryheid, genesing van siekes, die verkondiging van die nabyheid van die Koninkryk van God en indien die boodskap op dowe ore val, 'n oordeelsuitspraak wat steeds evangelie-verkondiging is, maar slegs op 'n ander wyse.

(5) Dit is egter duidelik dat dit nie die bedoeling van Lukas was om óf in 9:57-62, of in 10:1-24' $n$ bearbeidingswyse aan te bied nie. 
(b) Lukas 15:1-32: Die afbakening van hierdie Skrifgedeelte teenoor die voorafgaande en die daaropvolgende is ook opsigtelik duidelik. Drie perikope kan binne die gedeelte van mekaar onderskei word, naamlik 15:1-7, 15:8-10 en 15:11-32 wat tradisioneel bekend staan as die gelykenis van die afgedwaalde skaap, die gelykenis van die verlore penning en die gelykenis van die verlore seun. Oorsigtelik is die struktuur die volgende:

A. Die Fariseërs kritiseer Jesus dat $\mathrm{Hy}$ toelaat dat mense wat nie die regte gesindheid teenoor die Wet het nie, en derhalwe buite die verbond staan (die tollenaars en die sondaars) na sy leringe luister en dat Hy met hulle omgaan. Na aanleiding van hierdie kritiek hou Hy aan hulle die gelykenisse voor (verse 1-3).

B. (1) Jesus stel die retoriese vraag of ' $n$ herder dan nie die een van die honderd skape wat afdwaal, sal gaan soek nie (vers 4).

(2) Die herder is by die vind van die afgedwaalde bly en al sy vriende en bure word gevra om saam bly te wees (verse 5-6).

(3) So sal daar in die hemel ook blydskap oor een bekeerling wees; meer as oor die nege-en-negentig wat in hulle eie oë dink dat hulle die regte gesindheid teenoor die Wet besit en bekering daarom nie nodig het nie (vers 7 ).

C. (1) Jesus herhaal die retoriese vraag en dan met betrekking tot 'n vrou wat die een geldstuk wat (van die tien) weggeraak het, gaan soek het (vers 8 ).

(2) By die vind van die geldstuk is die vrou bly, en haar vriendinne en bure word versoek om saam bly te wees (vers 9).

(3) So sal daar voor die engele van God blydskap oor een bekeerling wees (vers 10 ).

D. (1) 'n Jongste van twee seuns verlaat die vaderhuis op 'n onbehoorlike wyse (verse 11-13).

(2) Vanweë ontbering en herinnering aan die oorvloed by die vaderhuis neem hy hom voor om terug te keer en wel met berou (verse 14-19).

(3) Hy voeg die daad by die woord. Die vader ontvang hom met groot blydskap (verse 20-24).

(4) Die oudste seun wil nie saam bly wees nie (verse 25-30).

(5) Die vader dring by die oudste daarop aan om saam bly te wees (verse 31-32).

\section{Opmerkinge:}

(1) Al drie die gelykenisse word deur Jesus voorgehou na aanleiding van die kritiek wat die Fariseërs en die Skrifgeleerdes teenoor Hom uitbring.

(2) Die nege en negentig "regverdiges", die nege geldstukke, en die oudste seun dui op die Fariseërs en die Skrifgeleerdes wat in 
hulle eie oë in die regte verhouding tot die Wet staan en daarom in regte verhouding tot God.

Daarteenoor is daar volgens die beskouing van die Fariseërs en Skrifgeleerdes diegene wat nie in die regte verhouding tot die Wet en derhalwe tot God staan nie, naamlik die tollenaars en die sondaars. Laasgenoemde word aangedui met die "verlore skaap", die "verlore penning" en die "verlore seun". Die optrede van die herder, die vrou en die vader dui op die wyse van optrede van God (in Christus) teenoor hierdie groep.

(3) Al drie perikope dra by om die skopus van hierdie hele Skrifgedeelte in die soeklig te plaas, naamlik 'n oproep aan die Fariseërs en die Skrifgeleerdes om netsoos die herder, die vrou en die vader wat uitnemend bly is oor die vind van die "verlorenes", dieselfde vreugde te betoon wanneer Christus dié opsoek wat verlore gaan.

(4) Ons het dus hier met' $n$ kontrovers van Jesus met die Fariseërs en die Skrifgeleerdes te doen. Dit is moontlik om die Fariseërs en Skrifgeleerdes wat saam met die tollenaars en sondaars immers deel uitmaak van een geloofsgemeenskap, hier in 'n sekere sin in hedendaagse terme "buitekerklikes" te noem. Sulke kontroverse in die evangelies moet egter myns insiens op die vlak van die arbeid onder Israel gestel word, en nie op die vlak van heidensending of die arbeid onder buitekerklikes nie.

(5) Uit die oogpunt van die Fariseërs en die Skrifgeleerdes kan ons miskien wel van Jesus se optrede teenoor die tollenaars en die sondaars praat as arbeid aan mense wat deur hulle lewenswandel te kenne gee dat hulle buite die verbond te staan gekom het. In hierdie lig beskou, is daar in hierdie Skrifgedeelte nie 'n konsekwente "bearbeidingswyse" teenwoordig nie, want in die eerste twee gevalle word die "afgedwaalde" gesoek en in die laaste geval keer die "afgedwaalde" self terug. Dit is verder duidelik dat Christus in al drie die gevalle 'n "bekering" van die afgedwaalde vereis. Die betekenis wat die woord "bekering" in hierdie konteks het, is om Jesus as die Messias te aanvaar.

(6) Uit die voorafgaande is dit dus duidelik dat dit nie die intensie van Lukas was om ' $n$ bepaalde bearbeidingswyse aan die orde te stel nie.

\subsection{Die dissipels/apostels in vroeë tyd:}

Twee seleksies uit die gedeeltes wat handel oor die optrede van die dissipels in die tyd kort na die kruisiging en opstanding van Christus, is hier gekies. Hulle is Johannes 20:19-29 en Handelinge $8: 4-25$.

(a) Johannes 20:19-29: Hierdie perikoop wat tradisioneel bekend staan as die berig oor die ongelowige Thomas maak deel uit van die 
evangelis Johannes se beriggewing oor die paasgebeure wat by hoofstuk 20:1 begin en by 20:29 afsluit. Vorentoe word die perikoop afgegrens met verse 30-31 wat die slot van die hele evangelie vorm. Terug gereken het die gedeelte vanaf 20:19 e.v. duidelik 'n ander motief as verse $1-18 .{ }^{8}$ Oorsigtelik sien die struktuur van die perikoop soos volg daaruit:

(1) Die opgestane Kurios verskyn op 'n wonderbaarlike wyse die Sondagaand aan sy dissipels. Hy groet hulle met die vredesgroet. Hy wys hulle sy hande en sy sy. Die dissipels sien die Kurios en is bly (verse 19-20).

(2) Hy groet hulle weer, en sê vir hulle: "Soos die Vader My gestuur het, stuur Ek julle ook." Hy blaas op hulle en sê: "Ontvang die Heilige Gees. As julle die mense hulle sondes vergewe; dan is dit vergewe. As julle dit vir hulle laat hou; dan is dit gehou (verse 21-22).

(3) Thomas was nie by hulle nie. Daarom (oun) sê hulle vir hom: "Ons het die Kurios gesien. Maar (de) hy sê: "As (ean + konunktief) ek nie sien en voel, sal ek nooit glo nie (verse 24-25).

(4) Die volgende Sondagaand was die dissipels bymekaar. En (kai) Thomas was saam met hulle. Jesus verskyn op 'n wonderbaarlike wyse aan hulle en groet hulle met die vredesgroet (vers 26).

(5) Daarna (eita) sê Hy vir Thomas: "Voel en kyk. Moenie ongelowig wees nie, maar gelowig." Thomas sê: "My Kurios en my Theos." Jesus antwoord: "Glo jy omdat jy sien? Salig dié wat nie sien nie en glo" (verse 27-29).

\section{Opmerkinge:}

(1) Die skopus van hierdie perikoop is die missionêre opdrag van die opgestane Kurios aan sy dissipels. Dit kan soos volg bewys word:

(a) 'n Vergelykende studie met die slotgedeeltes van die Matteusen Lukasevangelie toon opvallende ooreenkomste. Albei die ander twee evangelies sluit met' $n$ missionêre opdrag af. Lukas verbind ook hierdie opdrag met die gawe van die Heilige Gees.

(b) Uit die struktuur self: Die perikoop sluit met 'n saligspreking aan mense wat die evangelie sal hoor en glo. Dit het ongetwyfeld op die adres van die verkondigende kerk betrekking.

(2) Die beriggewing oor die afwesigheid van die twyfelende dissipel, Thomas, berus op ' $n$ tradisie wat nie deur die ander evangeliste vermeld word nie. Die invoeging daarvan hier moet in die lig van die skopus van die hele perikoop geinterpreteer word.

(3) Die rede vir die afwesigheid van Thomas word nie vermeld nie. Uit die kontekstuele oogpunt moet dit vanweë sy twyfel wees. Volgens die Lukasberig (24:36-49) het die dissipels bymekaar gekom om die paasgebeure te bespreek. Thomas se voorwaarde wat in die 
ean + konjunktiefkonstuksie gegiet is, stel dit duidelik dat hy nie die moontlikheid om in die opstandingsgebeure te glo, voorsien nie. ${ }^{9}$ Waarom sou hy dan saam met die ander dissipels bymekaar wil kom om diè gebeure te bespreek? Sy afwesigheid is dus wel vanweë sy ongeloof. Ons kan Thomas derhalwe min of meer as 'n "buitekerklike" reken.

(4) Die optrede van die ander dissipels teenoor Thomas moet as 'n bewuste bemoeienis verstaan word. Die skopus is die missionêre opdrag aan die dissipels, en dat die "vervreemde" Thomas vanweë baie oorweginge die eerste objek van hulle sending sou wees, is gewis. Want volgens Handelinge 1:20 e.v., word Mattias as apostel aangewys op grond daarvan dat die dissipels gereken het dat die kring van die Twaalf vol mòet wees, en Thomas se dwaling moet anders as diè van Judas Iskariot gesien word. In die lig van hierdie oortuiging dat die kring vol moes bly, wil dit dus lyk of die ander dissipels Thomas nie met rus sou laat nie.

(5) Die wyse van optrede teenoor Thomas bevat slegs die boodskap: "Ons het die Kurios gesien". Hierdie "sien" sluit beslis ook geloof in. Thomas maak "sien" die voorwaarde van pisteuo. Jesus sluit daarby aan met die gebruik van die woord in sy oproep tot geloof aan Thomas en in sy saligspreking. Die blydskap van die dissipels wanneer hulle die Kurios "sien" dui daarop dat hulle "geglo" het. Die woorde van die dissipels aan Thomas kan dus in 'n afgeleide sin as 'n oproep om geloof aan Thomas wees.

(6) Ons het hier weer eens soos in die geval van Lukas 9:51-10:24 met arbeid onder "buitekerklikes" binne die skopus van heidensending te make. Die noodsaak van die arbeid kom sterk ter sprake, maar 'n bepaalde "bearbeidingswyse" word nie aan die orde gestel nie behalwe ' $n$ oproep tot geloof.

(b) Handelinge 8:4-25: Die afgrensing van hierdie perikoop teen die voorafgaande en die daaropvolgende, is duidelik merkbaar. In die Griekse teks van die United Bible Societies is die opskrif: "The Gospel Preached in Samaria". ${ }^{10}$ Die struktuur vertoon 'n dialogiese patroon:

(1) Filippus verkondig die Evangelie in Samaria met gepaardgaande tekens van genesing van mense met onrein geeste en siektes (verse 4-8).

(2) Simon Magus het reeds al vir 'n lang tyd die Samaritane verstom met sy toorkunste. Die mense beskou hom as 'n soort godheid (verse 9-11).

(3) Filippus verkondig die evangelie. Baie mense kom tot geloof en word gedoop (vers 12).

(4) Simon het ook begin glo en is gedoop. Hy vergesel Filippus en is verstom oor die tekens en groot kragte wat hy sien (vers 13).

(5) Petrus en Johannes word deur die apostels in Jerusalem na 
Samaria gestuur. Hulle bid dat die Heilige Gees oor die jong-gelowiges mag kom. Met handoplegging ontvang hulle toe die Heilige Gees (verse 14-17).

(6) Simon bied die apostels geld aan dat hulle hom ook hierdie vermoë moet gee om met handoplegging die Heilige Gees aan mense mee te deel (verse 18-19).

(7) Petrus antwoord hom: (1) na die verderf met jou en jou geld. (2) jy is nie werklik een van ons nie, (3) bekeer jou van hierdie dwaling, (4) en bid tot die Kurios om jou te vergewe (verse 20-23).

(8) Simon antwoord: "Bid julle tot die Kurios vir my dat wat julle gesê het nie oor my kom nie" (vers 24).

(9) Petrus en Johannes keer terug na Jersualem, en verkondig onderweg die Evangelie in baie Samaritaanse dorpe (vers 25).

\section{Opmerkinge:}

(1) Ons het in hierdie perikoop met twee berigte te doen wat deur Lukas bymekaar gevoeg word om een skopus daar te stel, naamlik (a) die verspreiding van die Evangelie in Samaria, en (b) die verhaal van Simon Magus. Die skopus is die verspreiding van die evangelie in Samaria. Dit geskied deur die krag van die Heilige Gees wat eers deur Filippus werk, en daarna deur handoplegging wat as gawe aan die gelowiges, hulle lewe totaal verander. Hierdie verkondigingsaktiwiteit gaan gepaard met die uitdrywing van demone (deur die krag van die Heilige Gees).

(2) Simon Magus, eie aan sy magiese ingesteldheid, wil hierdie tēn dōrean t.o.v. Theou koop om daarmee vir hom 'n nog groter naam te maak, en seker ook met' $n$ winsmotief. Hy benader die hele aangeleentheid van die Heilige Gees as (bevrydende) gawe dus verkeerd. Hy tas die eer en majesteit van die Heilige Gees aan - diè Heilige Gees wat volgens die weergawe van Handelinge so kragtig aan die werk was.

(3) In Simon Magus het ons ongetwyfeld met 'n persoon te doen wat deur sy lewenswandel te kenne gegee het dat hy op pad uit die gemeenskap van die gelowiges is. Altans dit is 'n vraag of hy werklik ooit 'n gelowige was. Volgens vers 13 het hy egter wel tot die geloof gekom, en is gedoop. In hedendaagse terme kan Simon waarskynlik as 'n hipokriet beskrywe word.

(4) Die bearbeiding van Simon deur Petrus is nie vleiend nie, hoewel hy tog 'n oproep tot bekering doen: Wie met verkeerde motiewe glo en die Heilige Gees wil misbruik, het geen deel aan die gemeenskap van die gelowiges en die gawes van die Gees nie. So iemand bring verderf oor homself.

(5) Albei die motiewe, naamlik diè van die verspreiding van die evangelie in Samaria, en diè van Simon Magus, dra slegs by om die skopus te belig. Ons vind met ander woorde in hierdie perikoop 
weereens die motief van "arbeid onder buitekerklikes" binne die skopus van "heidensending". In albei gevalle kom die noodsaak van die verkondiging van die evangelie ter sprake. 'n Aanbieding van 'n "bearbeidingswyse" is egter nie die intensie van Lukas nie.

\subsection{Paulus:}

Twee seleksies wat baie met mekaar in gemeen het, is hier gekies. die een is die berig in Handelinge waar Lukas vir ons ' $n$ beskrywing van Paulus se eerste arbeid onder die Korintiërs gee, naamlik Handelinge 18:1-18(a), en die tweede is uit Paulus se eerste brief aan die Korintiërs self, naamlik 1 Korintiërs 1:18-2:5. Albei hierdie seleksies se strukture word eers oorsigtelik aangebied, voordat' $n$ aantal eksegetiese opmerkinge gemaak word wat albei seleksies sal dek. Verder word daar na nog twee seleksies uit die Corpus Paulinum gekyk, naamlik die inleiding tot die brief aan die Galasiërs (1:1-12), en die paraenetiese gedeelte in die brief aan die Kolossense (3:1-4:1).

(a) Handelinge 18:1-18(a): Hierdie perikoop grens hom na agter af teen die gebeure by die Areópagus en na vore teen die gebeure in Kengreë.

(1) In Korinte aangekom, gaan woon Paulus by Akwila en Prissilla. Hy gaan elke sabbat na die sinagoge en probeer Grieke en Jode tot die geloof in Christus oorreed (verse 1-4).

(2) Na die koms van Silas en Timoteus wy hy hom voltyds aan sy taak. Na aanhoudende verset en belediginge van die kant van die Jode, spreek hy ' $n$ oordeel oor hulle uit en gaan in die huis langs die sinagoge voort met sy taak, nadat hy uitdruklik verklaar het dat hy voortaan onder die heidene sal werk. Krispus, die hoof van die sinagoge, kom tot die geloof en so ook baie Korintiërs. Hulle word gedoop (verse 5-8).

(3) Die Jode slaag nie met 'n hofsaak teen Paulus voor Gallio, die goewerneur, nie (verse 9-17).

(4) Paulus vertrek saam met Prissilla en Akwila uit Korinte na Sirië (vers 18a).

(b) 1 Korintiërs 1:18-2:5: Hierdie gedeelte word gewoonlik in twee perikope verdeel, naamlik $1: 18-31$ en $2: 1-5$. die U.B.S.-teks gee respektiewelik aan elkeen die opskrif: "Christ the Power and Wisdom of God", en "Proclaiming Christ Crucified". Myns insiens is hierdie formele onderskeiding nie nodig nie, omdat die struktuur van die redevoering dit nie vereis nie. Die hele gedeelte staan verder ook in duidelike relasie met sowel die voorafgaande, as die daaropvolgende. Dit kan wel na agter afgegrens word teen verse 10-17, wat'n vermaning is teen partyskappe. Van 2:6 volg'n uiteensetting oor die wysheid van God. Die stuktuur van 1:18-2:5 is soos volg: 
(1) Opskrif: Die kruiswoord is dwaasheid vir die verlorenes, maar 'n krag van God vir die verlostes (vers 18).

(2) Waarom? God het dit in sy wysheid so beskik dat die wêreld met die beoefening van sy (die wêreld se) wysheid God nie leer ken het nie, en het besluit om mense te red deur die "dwaasheid" van die kerugma en so die wysheid van die wêreld dwaasheid gemaak. Die wat gered word, word dus nie gered omdat hulle die wysheid van die wêreld besit nie, maar omdat hulle glo. Hierdie geloof het nie deur die wysheid van die wêreld tot stand gekom nie, maar deur die dwaasheid van die prediking van die evangelie (verse 19-21).

(3) Wat is die wysheid van die wêreld wat deur die kerugma dwaas gemaak is? Dit is dat die Joods-georiënteerde lidmate na "tekens" vra en die Grieks-georiënteerde lidmate na wysheid soek (vers 22).

(4) Wat doen Paulus in hierdie situasie? (a) Hy verkondig (kērussein) die gekruisigde Christus. Dit is vir die Jode 'n ergenis en vir die Grieke dwaasheid. Maar vir die Jode en Grieke wat tot die geloof kom, is die boodskap van Christus die krag van God en die wysheid van God (verse 23-25).

(b) Hy herinner die Korintiërs daaraan hoe dit destyds gesteld was toe hulle tot die geloof gekom het (verse 26-31).

(5) Wat was destyds die aard en wyse van sy arbeid aan hulle? (a) $\mathrm{Hy}$ het die musterion van God nie aan hulle volgens 'n oorredende woord vanuit die wysheid van die wêreld verkondig (kataggellein) nie, maar hy het alleen Jesus Christus die Gekruisigde aan hulle bekend gemaak (2:1-2).

(b) Dit het hy met 'n eerbiedige verantwoordelikheid voor God gedoen (vers 3).

(c) Sy kerugma is nie gedra deur die wysheid van die wêreld nie, maar deur die manifestasie van die krag van die Gees (vers 4).

(6) Dit het hy gedoen sodat die Korintiërs se geloof nie op die wysheid van mense gefundeer is nie, maar op die krag van God (vers 5).

\section{Opmerkinge:}

(1) 'n Vergelyking van gedeeltes soos Handelinge 18:1-18(a) en 1 Korintiërs 1:18-2:5 vorm 'n belangrike onderbou in hierdie hele ondersoek. Want in die eerste plek kry ons 'n aanduiding van die kant van Lukas hoe hy die arbeid van Paulus aan die heidense Korintiërs aan ons wil voorstel, maar ook 'n terugblik van Paulus self oor dieselfde arbeid. Dit het in die tweede plek 'n verdere betekenis, naamlik dat ons binne die Korinte - perikoop ' $n$ aanduiding kry van die arbeid van Paulus onder dieselfde Korintiërs wat nou gevaar loop om vervreemd teenoor die ware "leer" te raak.

(2) In die Handelinge-perikoop het ons dus ongetwyfeld met arbeid aan heidene te maak, hoewel Paulus hom ook hier, soos elders, 
aanvanklik op die sinagoge toegespits het. Die skopus van diè perikoop vorm ' $n$ klein onderbou in die hele doel en struktuur van die boek Handelinge. Barclay M Newman en Eugene A Nida" ${ }^{11}$ het in die inleiding op hulle Translator's Handbook op Handelinge oortuigend aangetoon dat een van die mees opvallende temas in die boek die geografiese verspreiding van die Christendom vanaf Jerusalem na Rome is. Hierdie geografiese verspreiding van die evangelie word in ses fases verdeel en elke evangelisasie-stadium word met 'n opsommende opmerking afgesluit. Die tersake perikoop in Handelinge vorm 'n deel van die vyfde stadium waar die Kerk sy grense al sover as Europa uitgebrei het. Paulus se arbeid in Korinte en Efese is die fokuspunte van die aandag in hierdie vyfde fase van die vroeë evangelisasie. Lukas is ook daarop ingestel om in die Handelinge stap vir stap aan te toon hoe die engperspektief van die apostels, naamlik dat hulle eerlik van oortuiging was dat hulle evangelisasietaak nie universele implikasies het nie, mettertyd verander het. Die evangelie is vir Jode én heidene bedoel. En so het Lukas vanaf Hoofstuk 13 Paulus op die voorgrond geplaas. Paulus was van oortuiging dat God hom uitgekies het as die apostel vir die heidene, hoewel hy ook begerig was om die evangelie aan sy eie mense te bring. Hierdie twee opvallende temas van die boek Handelinge, naamlik die geografiese verspreiding van die Christendom en die "theological freedom of the Gospel from the confines of Judaism", word deur ons tersake perikoop gedien. Ons het dus hier met 'n perikoop te doen waarvan die skopus die sending aan die heidene is.

(3) Die inhoud van die arbeid in Korinte was volgens Lukas die verkondiging dat Jesus die Messias is en die daarby behorende bediening van die sakrament van die doop. ${ }^{12}$ Die lokaliteit en die gerigtheid van die arbeid word vermeld, maar nie 'n "bearbeidingswyse" nie, naamlik dat dit in die sinagoge begin het, later in 'n huis, aanvanklik deeltyds, later voltyds.

(4) Die begin van die Handelinge-perikoop noem dat Paulus vanaf Athene na Korinte gegaan het. Dikwels word beweer dat nadat die apostel probeer het om 'n huwelik tussen die evangelie en die Griekse filosofie in sy Areopagus-toespraak (Handelinge 17) te laat plaasvind, maar nie met sukses nie, hy hom voorgeneem het om voortaan van werskwyse te verander en niks anders meer as net die kruisboodskap te verkondig nie. Dan word daar verwys na ons Korinte-perikoop. Ons kan egter met C K Barrett ${ }^{13}$ saamstem dat ons hoegenaamd geen afleiding vanuit die Korinte-perikoop kan maak dat Paulus na die Areopagus-toespraak van werkwyse verander het nie. Ons kry eerder 'n beskrywing van sy normale praktyk. "He is not contrasting his evangelistic method in Corinth with that which he employed elsewhere, but with that which others employed in Corinth."

(5) 1 Korintiërs 1:18-2:5 kan beskou word as deel van ' $n$ teologiese 
fundering van Paulus se paraenese aan die afvallige Korintiese gemeente. Die struktuur van die redevoering in hierdie perikoop vertoon dié van ' $n$ diamant. Dit is ' $n$ wyse van beredenering wat by Paulus geliefd is. ${ }^{14} \mathrm{Hy}$ begin naamlik deur sy tema aan te kondig: Die Kruiswoord is dwaasheid vir die verlorenes, maar ' $n$ krag van God vir die verlostes (1:18). Hy eindig met ' $n$ herhaling van die tema in 2:5. Die middelstuk vorm die onderbou van hierdie tema. En dit is in hierdie middelstuk dat Paulus ons iets meedeel van die aard van die dwaling. Hy toon ons ook aan wat hy in die situasie wil doen. As deel van sy argument verwys hy na sy eerste arbeid aan die Korintiërs.

(6) Barrett som die dwaling goed op wanneer hy sê: "In fact in the Jewish demands for signs and the Greek quest for wisdom, we have the two expressions, religious and unreligious respectively, of manin-the-world, man alienated from God and manifesting his rebellion in anthropocentric existence"

(7) Ons vind in die Korinte-perikoop 'n vermelding deur die apostel self van sy arbeid in 'n "heidensituasie" én (wat ons kan noem) sy "arbeid onder buitekerklikes". Dit is opvallend dat hy in eersgenoemde geval die gebeurewoord, kataggellein, gebruik, en in laasgenoemde die gebeurewoord, kērussein. Albei hierdie woorde behoort tot die semantiese woordveld van kommunikasie.

Kataggellein is generies van aard, terwyl kērussein 'n addisionele komponent besit, naamlik dat die aksie meer offisieel geskied, dit wil sê met meer gesag, en dat die inhoud van die aksie belangrik en dringend is. Hier word dié twee woorde spoedig ná mekaar gebruik, en wil dit dus lyk of ons die stylvorm van reduksie het. Dit sluit onder andere in dat die wisseling van verbale tempusvorme (en hier die wisseling van lekseme binne dieselfde semantiese woordveld), kan dien om oorkarakterisering te voorkom. ${ }^{15}$ Dit wil dus lyk of ons nie meer as wat geregverdig is in die gebruik van hierdie twee woorde hier moet inlees nie. Dit is onwaarskynlik dat hier' $n$ doelbewuste betekenisverskil tussen hulle is. Die veiligste is om nie 'n onderskeid in bearbeiding op grond van die gebruik van hierdie twee woorde hier af te lei nie.

(8) Dit is verder opvallend dat Paulus uitdruklik verklaar dat die inhoud van sy arbeid, Jesus Christus, in albei gevalle is. Dit is nie duidelik of die verwysing na "die oorredende woorde van wysheid" slegs op ' $n$ alternatiewe inhoud van die arbeid betrekking het, of ook op ' $n$ bearbeidingswyse nie. Die uitdrukking, gedra deur die manifestasie van die krag van die Gees (vers 4), wys egter nie op 'n bearbeidingswyse nie. ${ }^{16}$

(9) Paulus ag dit blykbaar nie essensieel om veel oor die wyse van sy bearbeiding te praat nie. Hy noem wel dat hy die arbeid met eerbiedige verantwoordelikheid voor God verrig. Oor die inhoud van die arbeid bestaan daar geen twyfel nie. 
(c) Galásiërs 1:1-12: Die afgrensing van hierdie perikoop bied na agter uit die aard van die saak natuurlik geen probleme nie. Vorentoe is dit egter nie so maklik uit te maak waar dit afgegrens moet word nie. Die teksanalise dui egter daarop dat ons die perikoop by vers 12 moet afgrens. Dit lyk verder ook nie nodig om verse 1-5 onder ' $n$ afsonderlike seksie, naamlik die groet, in te deel nie. ${ }^{17}$ Baie oorsigtelik vind ons in parafraserende vorm vanuit die dieptestruktuur die volgende struktuur:

(1) Kyk verby die mens Paulus, kyk na God wat hom as apostel gestuur het (verse 1-5).

(2) Daar is mense wat die evangelie van Jesus Christus wil verander. Vir hulle is daar net een boodskap: Laat hulle 'n "anathema" wees (verse 6-9)!

(3) Paulus sê dat hy hom nie steur aan mense wat wil hê dat hy die evangelie volgens hulle inhoud moet aanbied nie. Hy is in diens van Christus en nie in diens van mense nie (vers 10).

(4) Weer eens: Die evangelie wat Paulus verkondig is nie kata anthrōpōn nie, dit wil sê hy is nie deur'n mens tot die taak aangewys nie; ook nie para anthrōpōn nie, dit wil sê hy tree nie op as 'n naprater van 'n boodskap wat hy by ander mense gehoor het nie. Christus het dit aan hom geopenbaar (verse 11-12).

\section{Opmerkinge:}

(1) Hierdie perikoop moet beskou word as die inleiding van die brief waar Paulus die ware evangelie en sy apostoliese gesag teenoor die Judaīstiese teëstanders in Galata verdedig. Dit doen hy na aanleiding van twee sleuteluitdrukkings, naamlik kata anthrōpōn en para anthrōpōn. 'n Uitbreiding van hierdie twee uitdrukkings word in die brief verder aangebied.

(2) Of ons hier die teëstanders moet beskou as "buitekerklikes" is 'n probleem. Tog toon hulle deur hulle leer en lewenswandel dat hulle van die ware leer afwyk en derhalwe op pad uit die Kerk is, hoewel hulle dit natuurlik nie self so opneem nie. Hulle dwaling bestaan hoofsaaklik daarin dat hulle ' $n$ plus by die versoeningsdaad van Christus nodig ag, naamlik 'n onderhouding van die Sabbat, en die Joodse vas- en feesdae, ensovoorts.

(3) Die bearbeidingswyse van Paulus is hier in die vorm van ' $n$ paraenese. Selfs die groet word daarvoor aangewend. Dit is belangrik om daarop te let dat Paulus in sy hantering van taal die belangrikste feite wat hy wil onderstreep dikwels nie (soos dit in die Transformasioneel-Generatiewe Grammatika bekend staan) in die basiese kernsinne stel nie, maar in die kommata. Dit in ag genome, kan ons in hierdie perikoop opmerk dat Paulus baie klem wil lê op die verlossingswerk van Jesus Christus (verse 1-5). 
(4) Dat die indikatief nie sonder die imperatief geld nie, word in die aanwending van die woord "anathema" duidelik.

(d) Kolossense 3:1-4:1: Die afbakening van hierdie Skrifgedeelte word gedoen op grond van die feit dat dit die paraenetiese gedeelte van die brief aan die Kolossense vorm. Nadat' $n$ teksanalise gedoen is, het dit egter geblyk dat 4:2-6 wat "literarkritisch" gesien by die paraenese hoort, eerder as ' $n$ inleiding tot die volgende deel van die brief gereken moet word, naamlik die slotgroet. Die tersake gedeelte dan, naamlik 3:1-4:1, kan in verskillende seksies verdeel word, wat op hulle beurt almal bydra om die een skopus te dien.

(1) Soek die dinge wat daarbo is, en nie op die aarde nie (verse (1-5).

(2) 'n Negatiewe paraenese om die werke van die oue mens te laat vaar (verse 6-11).

(3) 'n Positiewe paraenese om die werke van die nuwe mens te doen (verse 12-14).

(4) 'n Paraenese wat uit losstaande vermaninge bestaan (verse 15-16).

(5) 'n Samevattende oproep: "Wat julle ook al doen in woord of in daad, doen alles as ambassadeurs van Jesus Christus (vers 17).

(6) Die Huistafel. Hierdie vermaninge is chiasties georden met die deurlopende tema dat diens aan mekaar 'n uitdrukking is van diens aan God (verse 18-4:1).

\section{Opmerkinge}

(1) Vir die doel van hierdie ondersoek word daar nie op die vrae na die outentisiteit van die brief ingegaan nie. Ons huldig vir die doel hiervan die tradisionele opvatting dat Paulus die outeur is.

(2) Hierdie Skrifgedeelte word ingelei met oun. Die paraenese wat volg, verwys dus terug na waar Paulus die Kolossense oor hulle afvalligheid aanspreek met verwysing na die Christusgebeure, asook na hulle doop (hoofstuk 2:6-23).

(3) Wat die afvalligheid presies behels, word wyd deur Nuwe Testamentici gediskusseer. Dit is in elk geval duidelik dat dit Judaīsties-gnostiese trekke vertoon. Net soos in die geval van die Galataperikoop kan hier dus ook in ' $n$ afgeleide sin gepraat word van "arbeid onder buitekerklikes."

(4) In die aanwending van die voorwaardekonstruksie in die fundering van die volgende reeks vermaninge, is dit duidelik dat Paulus nie die indruk het dat die Kolossense ooit gedink het dat hulle nie deel het aan Christus se verlossingswerke nie. (ei plus indikatief wil semanties iets ander sê as ean plus die konjunktief). ${ }^{18}$ Paulus se bearbeidingswyse bestaan daarin om die "afvalliges" daarop te wys dat die imperatief noodsaaklik'n resultaat van die indikatief moet wees. 
Die imperatief bestaan opsommend daarin dat alles gedoen moet word soos dit ambassadeurs van Christus betaam. ${ }^{19}$

\section{Die Hebreërbrief}

'n Keuse van 'n seleksie uit hierdie brief is miskien goed, omdat dit 'n brief is wat op ' $n$ totaal ander vlak as die meeste ander Nuwe Testamentiese briewe lê. Slegs een seleksie is gemaak, naamlik 10:19-39. Dit is 'n gedeelte wat gewoonlik konsekwent by die debat oor die arbeid onder die buitekerklikes ter sprake is.

Hebreërs 10:19-39: Die afbakening van hierdie perikoop is ook gedoen op grond van die feit dat dit in geheel 'n paraenetiese gedeelte is. Hoewel die vasstelling van die dieptestruktuur met moeite geskied, is die oppervlaktestruktuur tog redelik eenvoudig, naamlik:

(1) Die oproep tot: (i) gemeenskapsbeoefening met God. (ii) die vashou aan die geloofsbelydenis. (iii) liefdediens aan mekaar. (iv) onderhouding van die onderlinge godsdiensoefening.

Hierdie oproep word in die werk wat Jesus Christus as die groot Hoëpriester gedoen het, gefundeer (verse 19-25).

(2) Die rede tot die oproep: (i) Sonder die imperatief wat moet spruit uit die indikatief van die genade (vergelyk die fundering in 1) geld die indikatief nie. (ii) Al wat oorbly is die oordeel en vuurgloed (verse 26-31).

(3) Die Finale oproep: Die gelowige moet vasstaan in sy geloofsoortuiging - juis wanneer hy in gedagte hou dat hy baie ter wille van hierdie oortuiging in die verlede gely het (verse $32-39)^{20}$.

\section{Opmerkinge:}

(1) Hierdie perikoop maak deel uit van die middelstuk van die Hebreërbrief, naamlik 4:14-10:39. Die middelstuk handel oor Jesus Christus die groot Hoëpreister. Dit vertoon verder 'n opvallende struktuur, naamlik dat dit met' $n$ paraenese begin (4:14-16) en met ' $n$ paraenese eindig (10:19-39). Albei hierdie paraenetiese gedeeltes grond hulle vermaninge op die fokus van die middelpunt, naamlik Jesus, ons groot Hoëpriester. ${ }^{21}$

(2) Grosheide ${ }^{22}$ onder andere het oortuigend aangetoon dat die paraenese van die brief die skopus van die brief in die geheel vorm. Volgens hom is die tersake perikoop die duidelikste spreke van hierdie skopus.

(3) Die dwalinge wat uit hierdie perikoop na vore kom, is ongeloof, afvalligheid, verharding. Ons kan dus sê dat dit hier gaan om mense wat deur middel van hulle lewenswandel te kenne gee dat hulle op pad uit die Kerk is. Die "bearbeiding" daarteenoor is die oproep tot geloof, volharding, gemeenskapsbeoefening en saligheid. 
Hierdie oproep word in die werk wat Jesus Christus gedoen het, gefundeer. Dit is opvallend dat die paraenese nie ' $n$ bepaalde adres in die gemeente het vir wie die brief bedoel is nie. Almal is die objek van vermaning.

\section{Algemene opmerkinge}

(1) Bepaalde aspekte van bearbeiding kom dus wel voor. In sommige gevalle verwys dit slegs na die lokaliteit en die gerigtheid van die arbeid. Die verskillende aspekte word in al die gevalle bepaal deur die heersende probleemsituasie. Dit kan daarom omskryf word as ad-hoc met betrekking tot die inhoud van die arbeid.

(2) In al die gedeeltes, by sommige eksplisiet, ander implisiet, is die inhoud van die arbeid aan beide kategorieë Jesus Christus en sy verlossingswerk. Die noodsaak van die arbeid is dikwels beklemtoon.

(3) Nooit is ' $n$ bepaalde bearbeidingswyse in die opbou van die perikoop se struktuur as ' $n$ sisteem aangebied nie. Selfs nie in die gevalle waar die opdrag van die arbeid die skopus van die gedeelte is nie, en ook nie in die een geval nie waar'n vermelding van "heidensending" en "arbeid onder buitekerklikes" 'n belangrike onderbou in die redevoering is (1 Kor 1:18-2:5).

(4) By Paulus en uit die Hebreërbrief-perikoop kan daar miskien wel 'n skema in "die arbeid onder buitekerklikes" afgelei word, naamlik die wys op die dwaling, die herinnering aan die verlede voor die afvalligheid, 'n oproep tot gehoorsaamheid, en 'n vermaning dat die indikatief nie sonder die imperatief geld nie. Hierdie skema word nie altyd in hierdie presiese volgorde opgebou nie. Dit is ' $n$ skema wat in elk geval ook deur die probleem-situasie bepaal word, en word nie as ' $n$ sisteem van bearbeidingswyse aangebied nie.

\section{Konklusie}

(1) Daar bestaan nie 'n algemeen geldende sisteem van bearbeidingswyse in die heidensending en die arbeid onder buitekerklikes in die onderhawige skrifgedeeltes van die Nuwe Testament nie. En omdat hierdie bevinding negatief is, kan die algemene reël gemaak word dat die Nuwe Testament nie 'n deurlopende sisteem ken nie. Geen vergelyking kan dus eintlik daarom tussen die bearbeidingswyse in die heidensending en die arbeid onder buitekerklikes op grond van die Nuwe Testament gemaak word nie. Die vraag na die gronde vir onderskeiding van bearbeidingswyse in hierdie twee kategorieë is dus 'n vraag ultra vires aan die Nuwe Testament. 
(2) Omdat die wyse van bearbeiding altyd deur die heersende probleem-situasie bepaal word, is dit vanselfsprekend dat die wyse van bearbeiding in die heidensending met dié in die arbeid onder buitekerklikes sal kan verskil. Die inhoud van die arbeid moet egter dieselfde bly. In beide kategorieë geld ook die noodsaak van die arbeid.

(3) Die voor-die-hand-liggende lyk dus of die kerk die bevoegdheid het om sy bearbeidingswyse in die heidensending en die arbeid onder buitekerklikes na gelang van die heersende probleemsituasie self te mag vasstel. Die enigste skriftuurlike vereiste lyk volgens hierdie studie dat die wyse van die arbeid die inhoud moet dien. Die inhoud mag nie aan die wyse ondergeskik gemaak word nie.

(4) As slotopmerking mag gestel word dat dit uit hierdie studie duidelik geword het dat dit nie nodig is om by die vasstelling van ' $n$ bepaalde aktuele bearbeidingswyse, in beide kategorieë, jou op 'n bepaalde Bybelteksvers te wil beroep nie. Só 'n onderneming lyk gevaarlik.

\section{REFERENCES TO CHAPTER "DIE VRAAG"}

1 D J Booysen - Julle sal my Getuies wees - Handleiding vir die Arbeid onder Buitekerklikes. HAUM, Pretoria.

2 Notule: 58ste Algemene Kerkvergadering van die Nederduitsch Hervormde Kerk van Afrika, bl. 141.

3 Vergelyk onder andere J Barr. The Semantics of Biblical Language, Oxford, 1961; E A Nida and C R Taber, The Theory and practice of Translation (Helps for translators), Leiden, 1969 en J P Louw, Semantiek van die Nuwe Testamentiese Grieks, Pretoria, 1976.

4 Vergelyk W Richter, Exegese als Literaturwissenschaft. Entwurf einer alttestamentlichen literaturtheorie und Methodologie, Göttingen, 1971 bl. 50-62 soos uiteengesit en toegepas deur J A Loader, Aspekte van die begrip menslike mag in die Ou Testament, ongepubliseerde doktorale verhandeling, Groningen, 1975.

5 Vir volledige teksanalise van 9:57-62, kyk JP Louw, Discourse Analysis and the Greek New Testament, gepubliseer in The Bible Translator, Vol. 24, No. 1, Jan. 1973, bl. 104 e.v.

6 Vir die verskillende teorieë vergelyk A Plummer, A Critical and Exegetical Commentary on the Gospel According to S. Luke, Edinburgh, 1969, bls. 269.

7 B M Metzger, A Textual Commentary on the Greek New Testament, UBS, 1971, bl. 150 e.v.

8 Vergelyk in hierdie verband R Bultmann, The Gospel of John, Oxford, 1971, bl. 689, vertaling van Das Evangelium des Johannes, Göttingen, 1964.

9 Vergelyk J A du Rand, ' $n$ Vernuwende hantering in die eksegese van Pauliniese Voorwaardesinne, gepubliseer in Teologie en Vernuwing, UNISA, 1975, bl. 45 e.v.

10 The Greek New Testament, Second Edition, UBS, 1968. bl. 445.

11 B M Newman en E N Nida, A Translator's Handbook on the Acts of the Apostels, UBS, London, 1972, bl. 2 e.v.

12 Die bediening van die sakrament van die doop is hier problematies, gesien in die lig dat Paulus in 1 Kor. 1:14 verklaar dat hy slegs Krispus en Gajus gedoop het. Vergelyk in hierdie verband die opmerking van $E$ Haenchen in sy kommentaar, Die Apostelgeschichte, Göttingen, 1965. 
13 C K Barrett, The First Epistle to the Corinthians, London, 1971, bl. 63.

14 Vergelyk in hierdie verband J P Louw, Semantiek van die Nuwe Testamentiese Grieks, Pretoria, 1967, bl. 123 e.v.

15 J P Louw, Verbale Aspek in Grieks, 'n rede gelewer by die 1971-linguistekongres in Pretoria, bespreek die opmerkinge van Paul Kiparsky, Foundations of Language 4, 1968 in verband met die sogenaamde historiese praesens, en maak dit van toepassing. Of die beginsel van reduksie bo alle twyfel op die wisseling van lekseme toegepas kan word, kan egter alleen deur 'n indringende ondersoek vasgestel word.

16 Vergelyk die opmerkinge van $\mathrm{H}$ Lietzmann, An de Korinther $I / I I$, Tübingen, 1969, bl. 11.

17 Vergelyk die UBS-teks.

18 Vergelyk in hierdie verband J A Durand, a.w.

19 Vir die interpretasie van die uitdrukking, en onomati Kuriou Lesou, in vers 17, vergelyk die kommentaar van E Lohse, Die Briefe an die Kolosser und an Philemon, Göttingen, 1968.

20 Vir die interpretasie van begrippe wat bydra tot die betekenis van hierdie perikoop soos proserchōmetha, homologia en egkataleipontes tēn episunagōgēn heautōn, vergelyk die Kommentare van $\mathrm{O}$ Michel, Der Briefe an die Hebreër, Göttingen, 1966 eb F W Grosheide, De Brief aan die Hebreër en de brief van Jakobus, Kampen, 1955. Vergelyk verder ook die artikel van G M M Pelser, A Translation Problem. Heb. 10:19-25, bl. 43 e.v., gepubliseer in Neotestamentica 8 (1974) onder die titel, Linguistics and Bible Translating. Vir die betekenis van parrẽsia in hierdie konteks kyk W S Vorster, The meaning of parrēsia in the Epistle to the Hebrews, bl. 51 e.v., gepubliseer in Neotestamentica 5 (1971) onder die titel AD HEBRAEOS.

21 Vergelyk W S Vorster, a.w., bl. 55, asook G M M Pelser, a.w., bl 44.

22 F W Grosheide, a.w., bl. 45. 